\title{
Soybean in succession to the residue of the sorghum/Paiaguás grass straw with Azospirillum brasilense ${ }^{l}$
}

\author{
Allan Hisashi Nakao ${ }^{2 *}$ (D), Marcelo Andreotti ${ }^{2}$, Deyvison de Asevedo Soares ${ }^{2}$, Viviane Cristina Modesto ${ }^{2}$, \\ Eduardo Augusto Pontes Pechoto ${ }^{2}$, Leandro Alves Freitas ${ }^{3}$
}

10.1590/0034-737X201966050009

\begin{abstract}
One of the alternatives to achieve agriculture with sustainability and reduction in production costs, mainly with fertilizers, is the formation of straw from the previous crop and the use of genus Azospirillum bacteria. The objective of this study was to evaluate the agronomic characteristics and yield of soybean, cultivated in areas under straw of sorghum regrowth inoculated or not with diazotrophic bacteria, single or intercropped with Paiaguás grass under Integrated System of Agricultural Production, in Cerrado region. The experiments were carried out in the field, in 2015 and 2016, in Selvíria, state of Mato Grosso do Sul. It was used a complete randomized block design, in a 2 × 2 × 2 factorial arrangement, with four replications, in two agricultural years: with the cultivation of dual-purpose and grain sorghum, single or intercropped with Paiaguás grass, with or without inoculating sorghum seeds with the bacterium Azospirillum brasilense. Soybean production and yield components were evaluated. Inoculation of grain or dual-purpose sorghum seeds with Azospirillum brasilense intercropped with Paiaguás grass, before soybean cultivation, increased the components of production and grain yield of soybean in succession.
\end{abstract}

Keywords: crop-livestock integration; Glycine $\max$ (L.) Merril; Urochloa brizantha.

\section{INTRODUCTION}

The no-tillage system (NTS) has presented advances in the productive processes of the Brazilian agriculture, gaining space among the producers, both for improving the chemical and physical properties of the soil as for helping in its biology. It is estimated that 60.7 million hectares in Brazil are cropped with grains using this system (Conab, 2017). Given the importance of the system, Bertol et al. (1998) emphasize the effectiveness of land cover, which has become an important factor in crop productivity.

Because they aggregate a succession of livestock and farming activities in the same area, the integrated croplivestock production systems (ICLPSs) have benefits on the environment and its biodiversity. It is a practice that allows the supply of high quality forage from late summer to early spring and a later straw formation for the insuccesion grain producing crop.

The importance of land cover using sorghum crop residues and Urochloa grass regrowth are identified as economic alternatives for crop rotation in the NTS as it produces high amount of dry matter for later decomposition and release of nutrients, resulting in soil protection by longer periods of time due to their high $\mathrm{C} / \mathrm{N}$ ratio. According to Kluthcouski \& Aidar (2003), brachiaria has the function of protecting the soil with the vegetal cover on the surface and of enhancing weed suppression as well as providing nutrients through the cycling of its straw.

\footnotetext{
Submitted on September 11 ${ }^{s t}, 2018$ and accepted on September 11 ${ }^{s t}, 2019$.

'This paper is part of the doctoral thesis of the first author. Study financed by Coordenação de Aperfeiçoamento de Pessoal de Nível Superior (CAPES).

${ }^{2}$ Universidade Estadual Paulista "Júlio de Mesquita Filho", Departamento de Fitossanidade, Engenharia Rural e Solos, Ilha Solteira, São Paulo, Brazil. allanhisashinakao@gmail.com; dreotti@agr.feis.unesp.br; deyvison_a.soares@hotmail.com; vivianemodesto@hotmail.com; eppechoto@gmail.com

${ }^{3}$ Universidade Tecnológica Federal do Paraná, Paraná, Brazil. leandroalvesfreitas@gmail.com

*Corresponding author: allanhisashinakao@gmail.com
} 
The search for new technologies aiming sustainability in agricultural production systems is increasing, and some authors have presented forms and alternatives for the saving of nitrogen fertilizers. One of them is the use of biological nitrogen fixation, which may supplement or even replace the use of these fertilizers (Bergamaschi, 2006). Thus, on account of the scarcity of studies in the literature on the use of inoculation of diazotrophic growth promoting bacteria in ICLPSs, studies in this area are relevant, especially with the use of sorghum intercropped with brachiaria in the season between harvests and residual straw for soybean in succession as an alternative for cropping in the Cerrado lowlands.

In this regard, the decomposition of forage plant residues may improve the crop performance during the complete development cycle of the plant, and may even increase its productivity. However, the result of the decomposition process depends on the nature of the plant material, on the amount of dry mass produced, on the management of the cover, on soil type and on the climatic conditions of the region (Kliemann et al., 2006). So, the objective of this study was to evaluate the agronomic characteristics and production of soybean yield, grown in areas with straw of regrowth of double aptitude or grain sorghum intercropped or not with Paiaguás grass and inoculated or not with Azospirillum brasilense.

\section{MATERIAL AND METHODS}

The experiment was carried out on Fazenda de Ensino, Pesquisa e Extensão (Teaching, Research and Extension Farm) owned by Faculdade de Engenharia/UNESP - Ilha Solteira Campus, located in the municipality of Selvíria, state of Mato Grosso do Sul (20²0’05" S and 51 24’26" W and a proximately $335 \mathrm{~m}$ above sea level). It presents 1370 $\mathrm{mm}$ of annual average rainfall, $23.5^{\circ} \mathrm{C}$ of average annual temperature and average relative air humidity of $64.8 \%$. Figure 1 shows data on rainfall, maximum, average and minimum temperature during the experimental period. The climate of the region is Aw, according to classification of Köppen, and characterized as tropical humid with rainy season in the summer and dry season in the winter. The soil of the experimental area, according to the Brazilian System of Soil Classification (Embrapa, 2013) is a typic dystrophic Red Latosol.

Prior to the experiment installation, 20 soil samples were collected at the $0.0-0.10$ and $0.10-0.20 \mathrm{~m}$ depths for fertility purposes, following the methodology proposed by Raij et al. (2001), which revealed the following chemical attributes values for the 0.0-0.10-m layer: $\mathrm{pH}\left(\mathrm{CaCl}_{2}\right)=5.4$; $16.0 \mathrm{mg} \mathrm{dm}^{-3}$ of P; 1.6; 27.0; 19.0; 28.0; 47.6 and 75.6 mmol $_{\mathrm{c}}$ $\mathrm{dm}^{-3}$ of $\mathrm{K}, \mathrm{Ca}, \mathrm{Mg}, \mathrm{H}+\mathrm{Al}, \mathrm{SB}$ and CEC, respectively; $24.0 \mathrm{~g}$ $\mathrm{dm}^{-3}$ of organic matter and base saturation $(\mathrm{V} \%)=63.0$, and for the $0.10-0.20$-m layer: $\mathrm{pH}\left(\mathrm{CaCl}_{2}\right)=5.5 ; 17.0 \mathrm{mg}$ $\mathrm{dm}^{-3}$ of P; 1.2; 25.0; 16.0; 28.0; 42.2 and $70.2 \mathrm{mmol}_{\mathrm{c}} \mathrm{dm}^{-3}$ of $\mathrm{K}, \mathrm{Ca}, \mathrm{Mg}, \mathrm{H}+\mathrm{Al}, \mathrm{SB}$ and CEC, respectively; $20.0 \mathrm{~g} \mathrm{dm}^{-3}$ of organic matter and base saturation $(\mathrm{V} \%)=60.0$.

There were two experiments with cultivation of Grain Sorghum and dual-purpose. The experimental design was a $2 \times 2 \times 2$ factorial scheme. The treatments were the two years of cultivation (2015 and 2016); in exclusive cultivation (single) of sorghum or in consortium with Paiaguás grass (Urochloa brizantha cv. BRS Paiaguás), with or without inoculation of sorghum seeds with the bacterium Azospirillum brasilense, with four replications. In March 2015 and 2016, respectively, the grain and dual-purpose sorghum were planted in the same place in both years, being in ICLPSs for silage material harvesting. A sowingfertilizer with haste-type furrower (knife) was used for NTS in a $0.45-\mathrm{m}$ spacing, with a density of 10 seeds $\mathrm{m}^{-1}$.

Diazotrophic bacteria (AbV5 and AbV6 strains) were supplied at a dose of $100 \mathrm{ml}$ of the commercial product $\left(2.0 \times 10^{9} \mathrm{CFU} / \mathrm{ml}\right)$ for $25 \mathrm{~kg}$ of seeds. The inoculation with the liquid inoculant was carried out in the seeds of sorghum cultivars before sowing, in the shade in both years. In both agricultural years, Paiaguás grass sowing was carried out simultaneously to the sorghum sowing, carried out with another sowing machine-fertilizer with double-disc type mechanism, disjoined for NTS, and sown between sorghum lines. The seeds were set at a depth of approximately $0.06 \mathrm{~m}$ at a spacing of $0.45 \mathrm{~m}$, using approximately $10 \mathrm{~kg} \mathrm{ha}^{-1}$ of viable pure seeds with $\mathrm{CV}=$ $60 \%$ in the two years of conduction.

After silage harvesting, the area was closed for 99 days for regrowth development. Following this procedure, the area was desiccated and cut aiming at the continuity of the no-tillage system. The soybean crop was implanted in succession, both years and on the same sorghum plots. Each experimental unit consisted of seven lines of sorghum spaced $0.45 \mathrm{~m}$ apart, with twenty meters in length, totaling $63 \mathrm{~m}^{2}$.

Soybean was mechanically sown on 11/17/2015 and $11 / 15 / 2016$ for the first and second years, respectively, using the same cultivar BMX Potência RR recommended for the region in both years. A sowing-fertilizer machine was used with rod-type furrower mechanism (knife) for NTS with a spacing of $0.45 \mathrm{~m}$ between rows and approximately 19 seeds per meter of furrow. Fertilization in the sowing furrow consisted of $60 \mathrm{~kg} \mathrm{ha}^{-1} \mathrm{P}_{2} \mathrm{O}_{5}$ and $\mathrm{K}_{2} \mathrm{O}$ and $56 \mathrm{~kg} \mathrm{ha}^{-1} \mathrm{P}_{2} \mathrm{O}_{5}$ and $\mathrm{K}_{2} \mathrm{O}$, in the first and second year, respectively.

Soybean seeds were treated with fipronil + pyraclostrobin $\left(50+5 \mathrm{~g}\right.$ a.i. $100 \mathrm{~kg}^{-1}$ seeds, respectively), and inoculated with Bradyrhizobium japonicum and $B$. elkanii (Semia 587 and Semia 5019 strains). According to the needs of the crop, insecticides and fungicides were 
applied twice in both years: (107.5 $\mathrm{g} \mathrm{ha}^{-1}$ a.i. methomyl, 80 and $10 \mathrm{~g} \mathrm{ha}^{-1}$ a.i. imidacloprid + beta-cyfluthrin and $60+24$ $\mathrm{g} \mathrm{ha}^{-1}$ a.i. azoxystrobin + cyproconazole $+0.5 \%$ mineral oil (v/v) or $107.5 \mathrm{~g} \mathrm{ha}^{-1}$ a.i. methomyl, $10 \mathrm{~g} \mathrm{ha}^{-1}$ a.i. chlorantraniliprole, 80 and $10 \mathrm{~g} \mathrm{ha}^{-1}$ a.i. imidacloprid + betacyfluthrin and $66.5+25 \mathrm{~g} \mathrm{ha}^{-1}$ a.i. of pyraclostrobin + epoxiconazole).

For the harvest in the first $(03 / 17 / 2016)$ and second $(03 / 03 / 2017)$ year, the productive characteristics and grain yield of the soybean were evaluated. So, the plants were collected from each plot in the three central rows at $4 \mathrm{~m}$ (useful area), where the plant population was determined, extrapolated to 1 ha. In addition, ten plants were randomly collected per experimental unit and the first pod insertion height, total number of pods per plant, average number of grains per pod and mass of 100 grains (13\% wet basis) were determined. In order to determine grain yield, 3 rows ( 2 meters each) of the plot were harvested, mechanically threshed, weighed, and later calculated and extrapolated to $\mathrm{kg} \mathrm{ha}^{-1}$ and corrected for the $13 \%$ moisture content.

The results were submitted to analysis of variance by the $\mathrm{F}$ test and the means were compared by the test of Tukey at $5 \%$ probability using SISVAR $^{\circledR}$ statistical software (Ferreira, 2011).

\section{RESULTS AND DISCUSSION}

The average values of the morphological components, production and yield of the 2015/16 and 2016/ 17 soybean harvests on the sorghum regrowth straw are presented in Table 1.

In the first year of soybean cultivation, plant height (PH), first pod insertion (FPIH) and final plant stand (FPS) were greater, which is justified by the lower amount of residual straw from sorghum regrowth this year. On the other hand, due to the greater amount of residual straw, planting and seedling emergence were difficult, decreasing its population, and because this cultivar had an indeterminate growth habit, it resulted in a greater production of lateral branches and smaller plant height. Nevertheless, for the first year, with larger populations, a greater leaf spacing and, consequently, higher heights (PH and FDIH) were observed. According to Mauad et al. (2010), more densified plantations increase the intraspecific competition of soybean plants for water, nutrients and mainly for light, resulting in etiolation.

Grain yield was significantly greater in the second year of cultivation and also when grown in an area where sorghum was intercropped with Paiaguás grass. In areas where A. granulosa was inoculated with A. brasilense, soybean presented significant increases in the number of grains per plant (NGP); however, with a reduction in the number of pods per plant (NPP) (Table 1).

It is verified in the soybean yield unfolding within modalities of intercropped or not with Paiaguás grass and years of cultivation that the highest values were achieved in the treatments intercropped with grass and in the second year of soybean cultivation (Table 2). This fact can be explained by the greater availability of nutrients from this intercropping straw, which improved the soil fertility, thus increasing the number of grains per pod and per plant (Table 1), determinants of greater grain yield even in smaller populations in relation to the first year. Therefore, the use of sorghum intercropped with Paiaguás grass, after two years of cultivation, with greater straw deposition, even in silage cultivation, is determinant for the increase in soybean yield as pointed out by Costa et al. (2015), after

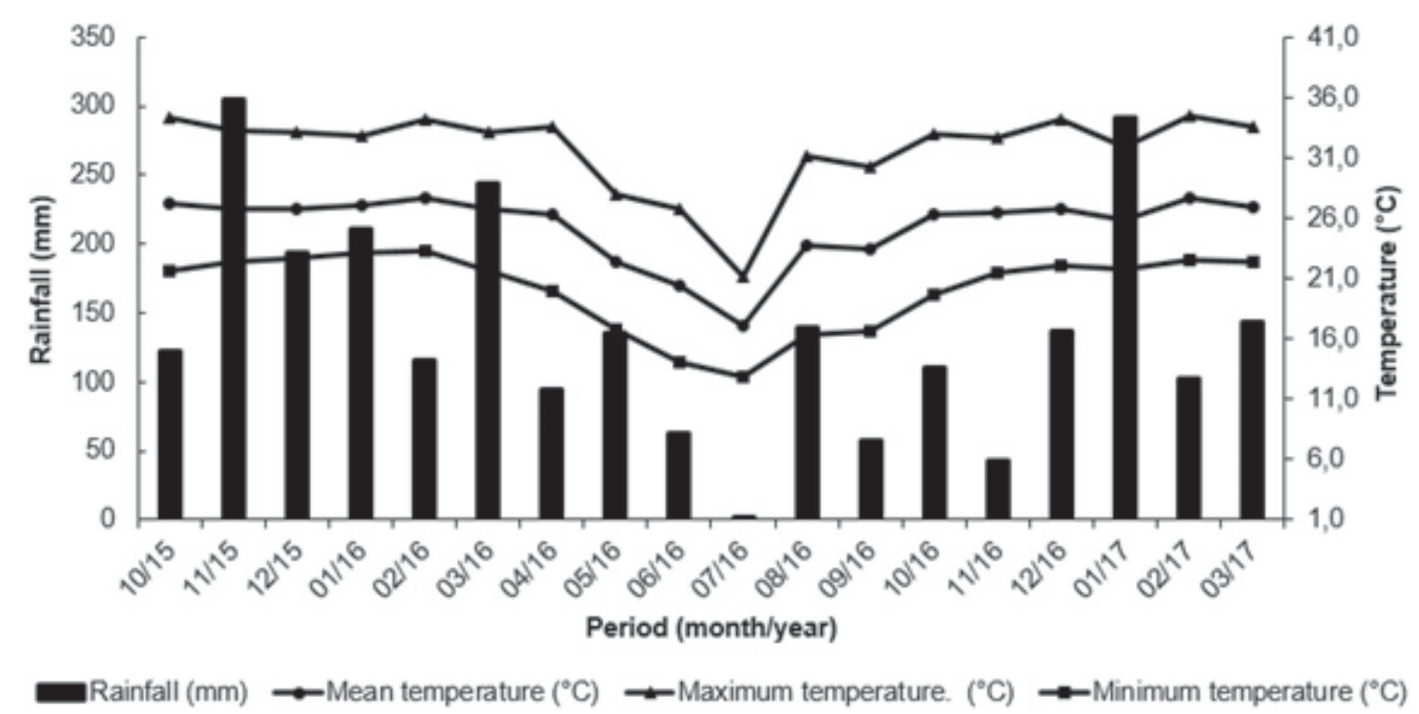

Figure 1: Rainfall and temperatures obtained from the weather station on Fazenda de Ensino, Pesquisa e Extensão at FE/UNESP in the municipality of Selvíria, Mato Grosso do Sul, from November/2015 to April/ 2017. 
harvesting maize silages and forage sorghum in different intercropings with Marandu and Tanzania grasses.

The unfolding of the interaction between intercropped or not with grass within the modality sorghum in succession inoculated or not with A. Brasiliense for the number of pods per plant (Table 3 ), shows that regardless of whether intercropped or not with grass, the inoculation of the grain sorghum seeds provided significant increments which may have an influence on the final soybean yield, showing the residual effect of sorghum inoculation over soybean by the hormonal effect of such bacterium in increasing the root volume of the plant (Barassi et al., 2008) and reducing the effects of water stress, which normally increases the abortion of pods.

Table 4 shows that the occurrence of an effect of the years on plant height, first pod insertion height, final plant stand and mass of one hundred grains of soybean in the dual-purpose sorghum regrowth straw and all the greater values in the first year, which characterizes the greatest vegetative growth in the largest population, due to the etiolation effect, with higher plant and first pod insertion heights, which resulted in greater intraspecific competition, reducing the number of grains per plant and per pod, explaining the compensatory effect of a greater 100-grain mass. However, in the second year, with a smaller population, even with a reduction in the mass of 100 grains, a significant increase occurred in the number of grains per plant and pod, and thus in the yield under straw of regrowth of dual-purpose sorghum, similar to that that also occurred in the areas with grain sorghum.

In addition, it should be highlighted the greater soybean yields in this second year due to the greater contribution of straw deposited by dual purpose-sorghum regrowth, which favors the initial development of the seedlings, allowing their longer longevity until the end of the crop cycle, probably due to the release of nutrients, retention of soil moisture, and weed control.

Table 2: Unfolding of significant interactions between years $x$ Paiaguás grass intercropped with grain sorghum for the yield of soybean in succession. Selvíria-MS

\begin{tabular}{|c|c|c|}
\hline \multirow{2}{*}{ TREATMENT } & \multicolumn{2}{|c|}{ Paiaguá grass } \\
\hline & With & Without \\
\hline & \multicolumn{2}{|c|}{$\operatorname{PROD}\left(\mathrm{kg} \mathrm{ha}^{-1}\right)$} \\
\hline $1^{\text {st }}$ year & $3385 \mathrm{bA}$ & $3301 \mathrm{aA}$ \\
\hline $2^{\text {nd }}$ year & $4954 a A$ & $3816 \mathrm{aB}$ \\
\hline
\end{tabular}

Means followed by different lower-case letter in the column and upper-case letter in the row are not different from each other by the test of Tukey at $5 \%$ of probability.

Table 1: Components of production and yield of soybean cropped under grain sorghum regrowth straw. Selvíria-MS

\begin{tabular}{|c|c|c|c|c|c|c|c|c|}
\hline \multirow{2}{*}{ Treatment } & PH & FPIH & NPP & NGP & NGV & FPS & \multirow{2}{*}{$\frac{\text { M100 }}{(\mathrm{g})}$} & \multirow{2}{*}{$\frac{\text { PROD }}{\left(\mathrm{kg} \mathrm{ha}^{-1}\right)}$} \\
\hline & \multicolumn{2}{|c|}{$(\mathrm{cm})$} & \multicolumn{4}{|c|}{$\left(n^{0}\right)$} & & \\
\hline \multicolumn{9}{|l|}{ Sorghum } \\
\hline $1^{\text {st }}$ Year & $110.2 \mathrm{a}$ & $19.5 \mathrm{a}$ & 39.0 & $78.3 b$ & $2.0 \mathrm{~b}$ & $347.530 \mathrm{a}$ & 14.2 & $3343 b$ \\
\hline $2^{\text {nd }}$ Year & $103.5 b$ & $14.4 \mathrm{~b}$ & 41.2 & $94.6 \mathrm{a}$ & $2.3 \mathrm{a}$ & $295.833 b$ & 13.7 & $4385 a$ \\
\hline \multicolumn{9}{|l|}{ Grass } \\
\hline With & 107.6 & 16.8 & 40.4 & 89.4 & 2.2 & 323.842 & 13.7 & $4170 \mathrm{a}$ \\
\hline without & 106.0 & 17.0 & 39.8 & 83.5 & 2.1 & 319.521 & 14.1 & $3558 b$ \\
\hline \multicolumn{9}{|l|}{ Inoculation } \\
\hline With & 107.8 & 16.6 & $35.7 b$ & $94.6 \mathrm{a}$ & 2.1 & 313.734 & 14.0 & 4027 \\
\hline Without & 105.9 & 17.2 & $44.4 \mathrm{a}$ & $78.3 b$ & 2.1 & 329.629 & 13.8 & 3701 \\
\hline \multicolumn{9}{|l|}{ F test } \\
\hline Year (A) & $16.77 * *$ & $79.2 * *$ & $2.19 \mathrm{~ns}$ & $13.88 * *$ & $13.81 * *$ & $35.28 * *$ & $1.90 \mathrm{~ns}$ & $28.11 * *$ \\
\hline Grass (C) & $0.89 \mathrm{~ns}$ & $0.11 \mathrm{~ns}$ & $0.17 \mathrm{~ns}$ & $1.83 \mathrm{~ns}$ & $1.76 \mathrm{~ns}$ & $0.24 \mathrm{~ns}$ & $1.04 \mathrm{~ns}$ & $9.67 * *$ \\
\hline Inoculation (I) & $1.34 \mathrm{~ns}$ & $1.10 \mathrm{~ns}$ & $34.0 * *$ & $14.00 * *$ & $0.42 \mathrm{~ns}$ & $3.33 \mathrm{~ns}$ & $0.18 \mathrm{~ns}$ & $2.74 \mathrm{~ns}$ \\
\hline$Y \times G$ & $1.00 \mathrm{~ns}$ & $0.08 \mathrm{~ns}$ & $2.42 \mathrm{~ns}$ & $0.15 \mathrm{~ns}$ & $1.12 \mathrm{~ns}$ & $0.02 \mathrm{~ns}$ & $1.04 \mathrm{~ns}$ & $7.20 *$ \\
\hline Y x I & $0.01 \mathrm{~ns}$ & $3.03 \mathrm{~ns}$ & $0.36 \mathrm{~ns}$ & $0.15 \mathrm{~ns}$ & $0.42 \mathrm{~ns}$ & $1.16 \mathrm{~ns}$ & $0.20 \mathrm{~ns}$ & $0.39 \mathrm{~ns}$ \\
\hline G x I & $0.64 \mathrm{~ns}$ & $0.28 \mathrm{~ns}$ & $4.50 *$ & $0.54 \mathrm{~ns}$ & $0.76 \mathrm{~ns}$ & $0.18 \mathrm{~ns}$ & $0.04 \mathrm{~ns}$ & $0.77 \mathrm{~ns}$ \\
\hline Y x Gx I & $0.01 \mathrm{~ns}$ & $0.01 \mathrm{~ns}$ & $1.99 \mathrm{~ns}$ & $0.97 \mathrm{~ns}$ & $0.07 \mathrm{~ns}$ & $0.04 \mathrm{~ns}$ & $2.65 \mathrm{~ns}$ & $1.04 \mathrm{~ns}$ \\
\hline DMS & 3.40 & 1.20 & 3.08 & 9.08 & 0.15 & 18.099 & 13.95 & 408 \\
\hline $\mathrm{CV}(\%)$ & 4.33 & 9.63 & 10.45 & 14.28 & 9.68 & 7.65 & 7.27 & 14.38 \\
\hline
\end{tabular}

Means followed by the same letter in the column are not different from each other by the test of Tukey at $5 \%$ of probability. $* *$ and $*$ : significant at the 1 and 5\% level, respectively. ns: not-significant. PH: plant height; FPIH: first pod insertion height; NPP: number of pods per plant; NGP: number of grains per plant; NGV: number of grains per pod; FPS: final plant stand; M100: one hundred grain mass and PROD: productivity. 
Regarding first pod insertion height, the values met those found in the literature for adequate mechanized harvest, which according to Peixoto \& Souza (2002), should be close to 15 or $20 \mathrm{~cm}$.

Overall, the results of soybean populations under straw of grain sorghum (Table 1) and dual-purpose sorghum (Table 4) had the same behavior; therefore even with differences among stands, their productivity increased and may be justified by the capacity that the cultivar used (BMX Potência RR), of indeterminate growth, that when in a varied spatial arrangement of plants, has a compensating effect on the number of branches, pods

Table 3: Unfolding of Paiaguás grass $\mathrm{x}$ grain sorghum inoculated with $A$. brasilense, for number of pods per plant (NPP) of soybean in succession. Selvíria-MS

\begin{tabular}{lcc}
\hline \multirow{2}{*}{ TREATMENT } & \multicolumn{2}{c}{ Inoculation } \\
\cline { 2 - 3 } & \multicolumn{3}{c}{ With } & Without \\
\hline With grass & $43.1 \mathrm{aA}$ & $37.6 \mathrm{aB}$ \\
Without grass & $45.7 \mathrm{aA}$ & $33.9 \mathrm{aB}$ \\
\hline
\end{tabular}

Means followed by different lower-case letter in the column and upper-case letter in the row are not different from each other by the test of Tukey at $5 \%$ of probability. and grains per plant, inversely proportional to the variation of its plant stand. Likewise, the increase in productivity may be attributable to the increase in nutrients provided by sorghum regrowth, where according to the study by Pitta et al. (2001), sorghum has the capacity to increase nutrient extractions ( $\mathrm{N}, \mathrm{P}, \mathrm{K}, \mathrm{Ca}, \mathrm{Mg}$ and $\mathrm{S}$ ) in a linear way in relation to productivity levels, where the largest requirement of sorghum refers to $\mathrm{N}$ and $\mathrm{K}$, followed by $\mathrm{Ca}, \mathrm{Mg}$ and $\mathrm{P}$. Another factor to be considered is the record of the cultivation area, which had been under NTS for over 10 years, and to the soil fertility itself and cultivation conditions, where rainfall promoted a better crop development, even in the dry season.

The results showed that the soybean sowing on the dual-purpose sorghum regrowth intercropped or not with Paiaguás grass is feasible, especially when inoculating the previous sorghum with $A$. brasilense (Table 4) since they promoted a significant increase in soybean yield when sown in areas that had received bacteria inoculations for two years, demonstrating the residual effect of the inoculation of the area (previous crop) and the hormonal effect of this bacterium on increasing root volume (Barassi et al., 2008), which may reduce the effects of water stress, since it normally increases pod abortion (Table 5).

Table 4: Production and yield components of soybean grown under dual-purpose regrowth straw. Selvíria-MS

\begin{tabular}{|c|c|c|c|c|c|c|c|c|}
\hline \multirow{2}{*}{ Treatments } & PH & FDIH & NPP & NGP & NGP & FPS & \multirow{2}{*}{$\frac{\text { M100 }}{(\mathrm{g})}$} & \multirow{2}{*}{$\frac{\text { PROD }}{\left(\mathrm{kg} \mathrm{ha}^{-1}\right)}$} \\
\hline & \multicolumn{2}{|c|}{$(\mathbf{c m})$} & \multicolumn{4}{|c|}{$\left(\mathrm{n}^{\mathrm{o}}\right)$} & & \\
\hline \multicolumn{9}{|l|}{ Sorghum } \\
\hline $1^{\text {st }}$ year & $112.2 \mathrm{a}$ & $18.5 \mathrm{a}$ & 36.8 & $77.1 \mathrm{~b}$ & $2.0 \mathrm{~b}$ & $348.611 \mathrm{a}$ & $14.5 \mathrm{a}$ & $3409 b$ \\
\hline $2^{\text {nd }}$ year & $105.4 \mathrm{~b}$ & $15.1 \mathrm{~b}$ & 38.0 & $84.5 \mathrm{a}$ & $2.2 \mathrm{a}$ & $323.958 b$ & $13.5 b$ & $3990 \mathrm{a}$ \\
\hline \multicolumn{9}{|l|}{ Grass } \\
\hline With & 107.6 & 16.7 & 37.9 & 81.1 & 2.1 & 335.185 & 13.9 & 3761 \\
\hline without & 110.0 & 16.9 & 36.9 & 80.5 & 2.1 & 337.384 & 14.1 & 3638 \\
\hline \multicolumn{9}{|l|}{ Inoculation } \\
\hline with & 109.1 & 17.2 & 38.2 & 82.6 & 2.1 & $314.158 b$ & 14.2 & $3910 a$ \\
\hline Without & 108.4 & 16.4 & 36.6 & 79.1 & 2.1 & $358.410 \mathrm{a}$ & 13.8 & $3489 b$ \\
\hline \multicolumn{9}{|l|}{ F test } \\
\hline Year (Y) & $18.69 * *$ & $51.32 * *$ & $1.33 \mathrm{~ns}$ & $7.62 *$ & $8.90 * *$ & $7.22 *$ & $9.89 * *$ & $2.31 * *$ \\
\hline Grass $(\mathrm{G})$ & $2.34 \mathrm{~ns}$ & $0.30 \mathrm{~ns}$ & $0.81 \mathrm{~ns}$ & $0.04 \mathrm{~ns}$ & $0.57 \mathrm{~ns}$ & $0.05 \mathrm{~ns}$ & $0.29 \mathrm{~ns}$ & $0.91 \mathrm{~ns}$ \\
\hline Inoculation(I) & $0.24 \mathrm{~ns}$ & $2.58 \mathrm{~ns}$ & $2.08 \mathrm{~ns}$ & $1.71 \mathrm{~ns}$ & $0.02 \mathrm{~ns}$ & $23.26^{* *}$ & $1.52 \mathrm{~ns}$ & $10.65^{* *}$ \\
\hline$Y \times G$ & $0.42 \mathrm{~ns}$ & $1.19 \mathrm{~ns}$ & $0.03 \mathrm{~ns}$ & $2.45 \mathrm{~ns}$ & $2.75 \mathrm{~ns}$ & $1.82 \mathrm{~ns}$ & $0.30 \mathrm{~ns}$ & $3.56 \mathrm{~ns}$ \\
\hline Y x I & $0.30 \mathrm{~ns}$ & $0.01 \mathrm{~ns}$ & $4.42 *$ & $0.90 \mathrm{~ns}$ & $1.75 \mathrm{~ns}$ & $3.20 \mathrm{~ns}$ & $0.04 \mathrm{~ns}$ & $0.51 \mathrm{~ns}$ \\
\hline G x I & $1.59 \mathrm{~ns}$ & $0.33 \mathrm{~ns}$ & $3.59 \mathrm{~ns}$ & $1.51 \mathrm{~ns}$ & $0.25 \mathrm{~ns}$ & $0.14 \mathrm{~ns}$ & $3.28 \mathrm{~ns}$ & $6.62^{*}$ \\
\hline$Y \times G \times I$ & $1.97 \mathrm{~ns}$ & $0.08 \mathrm{~ns}$ & $2.72 \mathrm{~ns}$ & $2.51 \mathrm{~ns}$ & $1.53 \mathrm{~ns}$ & $1.97 \mathrm{~ns}$ & $1.85 \mathrm{~ns}$ & $3.29 \mathrm{~ns}$ \\
\hline DMS & 3.26 & 1.01 & 2.24 & 5.52 & 0.09 & 19.080 & 0.67 & 267 \\
\hline $\mathrm{CV}(\%)$ & 4.08 & 8.17 & 8.17 & 9.30 & 5.82 & 7.72 & 6.58 & 9.85 \\
\hline
\end{tabular}

Means followed by the same letter in the column are not different from each other by the test of Tukey at $5 \%$ of probability. ** and $*$ : significant at the 1 and 5\% level, respectively. ns: not-significant. PH: plant height; FPIH: first pod insertion height; NPP: number of pods per plant; NGP: number of grains per plant; NGV: number of grains per pod; FPS: final plant stand; M100: one hundred grain mass and PROD: productivity. 
In the unfolding the interaction between years of dualpurpose sorghum cultivation with or without inoculation, it is verified that in the second year of cultivation with the inoculation, an increase occurred in the soybean NPP (Table 5), corroborating the previously discussed hormonal effect of the bacteria on root growth and on reducing the effects of water stress, which normally increases the abortion of pods. According to Okon \& Vanderleyden (1997), Azospirillum bacteria promote gains in productivity of important crops in the most varied climate and soil conditions; not only for increasing the $\mathrm{N}_{2}$ biological fixation but also for helping to increase the absorption surface of the plant roots and, consequently, to increase the exploited soil substrate volume, which is fundamental to the nutrient absorption. This finding is justified by the fact that the inoculation modifies the morphology of the root system, by increasing the number of rootlets as well as the diameter of the lateral and adventitious roots.

In the unfolding of the interactions between with or without Paiaguás grass and with or without the inoculation of the previous sorghum for the yield of the soybean sown on dual-purpose sorghum regrowth (Table 6), it is verified that the intercropping between the forage with Azospirillum brasilense inoculated sorghum provided greater soybean grain yield, demonstrating that the effect of the bacteria is more significant when there is a greater amount of straw on the soil, which may allow some

Table 5: Unfolding of the significant interaction between years $x$ Paiaguás grass intercropped with dual-purpose sorghum for number of pods per plants of soybean in succession. Selvíria-MS

\begin{tabular}{lcc}
\hline \multirow{2}{*}{ TREATMENT } & \multicolumn{2}{c}{ Inoculation } \\
\cline { 2 - 3 } & With & Without \\
\hline & \multicolumn{3}{c}{ NVP } \\
\hline $1^{\text {st }}$ year & $36.4 \mathrm{bA}$ & $37.1 \mathrm{aA}$ \\
$2^{\text {nd }}$ year & $39.9 \mathrm{aA}$ & $36.1 \mathrm{aB}$ \\
\hline
\end{tabular}

Means followed by different lower-case letter in the column and upper-case letter in the row are not different from each other by the test of Tukey at $5 \%$ of probability.

Table 6: Unfolding of the interaction between Paiaguás grass $x$ dual-purpose sorghum inoculated with $A$. brasilense for grain yield of soybean in succession. Selvíria-MS

\begin{tabular}{|c|c|c|}
\hline \multirow{2}{*}{ TREATMENT } & \multicolumn{2}{|c|}{ Inoculation } \\
\hline & With & Without \\
\hline & \multicolumn{2}{|c|}{ PROD $\left(\mathrm{kg} \mathrm{ha}^{-1}\right)$} \\
\hline Grass & $4137 \mathrm{aA}$ & $3385 \mathrm{aB}$ \\
\hline Without Grass & $3682 \mathrm{bA}$ & $3593 \mathrm{aA}$ \\
\hline
\end{tabular}

Means followed by different lower-case letter in the column and upper-case letter in the row are not different from each other by the test of Tukey at $5 \%$ of probability. enhancements in nutrient cycling and soil physicochemical conditions. According to Piano (2017), when integrated systems are well managed, soybean yield is increased, making it a viable option for the producer. In addition, for the continuity of the no-tillage system, the soybean cropped in NTS has the capacity to promote improvements in the physical and biological part of the soil (Salton et al., 2014).

According to Costa et al. (2014), intercropping is one way of raising the productivity of integrated production systems. In this context, among the benefits of this production system, the advantages related to the conservation and improvement of soil fertility should be considered.

\section{CONCLUSION}

Increments occurred in the number of pods per plant and in the yield of soybean in succession as a result of the sorghum (grain and dual-purpose) regrowth straw with the Paiaguás grass, and especially when inoculating the previous sorghum with Azospirillum brasilense.

\section{ACKNOWLEDGEMENTS, FINANCIAL SUPPORT AND FULL DISCLOSURE}

The authors would like to thank the funding agencie CAPES.

The authors declare that there are no conflicts of interest in the conduct and publication of the work.

\section{REFERENCES}

Barassi CA, Sueldo RJ, Creus CM, Carrozzi LE, Casanovas WM \& Pereyra MA (2008) Potencialidad de Azospirillum en optimizer el crecimiento vegetal bajo condiciones adversas. In: Cassán FD \& Garcia de salamone I (Ed.) Azospirillum spp.: cell physiology, plant interactions and agronomic research in Argentina. Argentina, Asociación Argentina de Microbiologia. p. 49-59.

Bergamaschi AF, Passipiéri M, Veriano filho WV, Isepon OJ \& Correa LA (2006) Qualidade e valor nutritivo de silagens de capim-marandu (B. brizantha cv. Marandu) produzidas com aditivos ou forragem emurchecida. Revista Brasileira de Zootecnia, 35:1454-1462.

Bertol I, Ciprandi O, Kurtz C \& Baptista AS (1998) Persistência dos resíduos culturais de aveia e milho sobre a superfície do solo em semeadura direta. Revista Brasileira de Ciência do Solo, 22:705-712.

Conab - Companhia Nacional de Abastecimento (2017) Acompanhamento da safra brasileira de Grãos. v. 4. Safra 2016/17: décimo levantamento. Brasília, Conab. 164 p.

Costa NR, Andreotti M, Buzetti S, Lopes KSM, Santos FG \& Pariz CM (2014) Acúmulo de macronutrientes e decomposição da palhada de braquiárias em razão da adubação nitrogenada durante e após o consórcio com a cultura do milho. Revista Brasileira de Ciência do Solo, 38:1223-1233.

Costa NR, Andreotti M, Lopes KSM, Yokobatake KL, Ferreira JP, Pariz CM, Bonini CSB \& Longhini VZ (2015) Atributos do solo e acúmulo de carbono na integração lavoura-pecuária em sistema plantio direto. Revista Brasileira de Ciência do Solo, 39:852-863. 
Embrapa (2013) Centro Nacional de Pesquisa dos Solos. 3.ed. Brasília, Embrapa-SPI, 353 p.

Ferreira DF (2011) Sisvar: a computer statistical analysis system. Ciência e Agrotecnologia, 35:1039-1042.

Kliemann HJ, Braz AJBP \& Silveira PM (2006) Taxa de composição de resíduos de espécies de cobertura em Latossolo Verme1ho Distroférrico. Pesquisa Agropecuária Tropical, 36:21-28.

Kluthcouski J \& Aidar H (2003) Uso da integração lavoura-pecuária na recuperação de pastagens degradadas. In: Kluthcouski J, Stone LF \& Aidar H (Ed.) Integração lavoura-pecuária. Santo Antonio de Goiás, Embrapa Arroz e Feijão. p. 185-223.

Mauad M, Silva TLB, Almeida Neto AI \& Abreu VG (2010) Influência da densidade de semeadura sobre características agronômicas na cultura da soja. Revista Agrarian, 03:175-181.

Okon Y \& Vanderleyden J (1997) Root-associated Azospirillum species can stimulate plants. Applied and Environment Microbiology, 06:366-370.

Peixoto MF \& Souza IF (2002) Efeitos de doses de imazamox e densidades de sorgo (Sorghum bicolor (L.) Moench) em soja (Glycine $\max ($ L.) Merril) sob plantio direto. Ciência e Agrotecnologia, 26:252-258.
Piano JT (2017) Propriedades físicas, resíduos culturais e soja em sucessão à aveia pastejada em sistema de integração lavourapecuária. Tese de Doutorado. Universidade Estadual do Oeste do Paraná, Marechal Cândido Rondon. 72p.Pitta GVE, Vasconcellos CA \& Alves VMC (2001) Fertilidade do solo e nutrição mineral do sorgo forrageiro. In: Cruz JC, Pereira Filho IA, Rodrigues JAS \& Ferreira JJ (Ed.) Produção e utilização de silagem de milho e sorgo. Sete Lagoas, Embrapa Milho e Sorgo. p. 519-544.

Raij B Van, Andrade JC, Cantarella H \& Quaggio JA (2001) Análise química para avaliação da fertilidade de solos tropicais. Campinas, Instituto Agronômico. 284 p.

Salton JC, Mercante FM, Tomazi M, Zanatta JA, Concenço G, Silva WM \& Retore M (2014) Integrated crop-livestock system in tropical Brazil: Toward a sustainable production system. Agriculture, 190:70-79. 